\title{
Assessment of Yield Gaps and Economics through Frontline Demonstration in Participatory Mode on Chickpea (Cicer arietinum L.) under Eastern Zone of Haryana
}

Munish Leharwan, Mohar Singh, Rakesh Kumar, Pankaj Kumar Saraswat, Yogesh Kumar, T.V. Arun Kumar

$10.18805 /$ LR-4779

\begin{abstract}
Background: Cluster frontline demonstration (CFLD) with improved technology plays a vital role in enhancing the production potential of pulses as well as socio-economic level of farmers and it also proved that it improves soil heath through crop diversification by optimizing diversified microhabitats that benefit soil microbial community.

Methods: KVK, ICAR-NDRI, Karnal (Haryana) conducted 220 demonstrations on chickpea variety HC-1 and HC-5 over an area of 80 ha during Rabi season 2017-18 to 2020-21. The demonstrated technology was improved variety HC-1 and HC-5, optimum seed rate and spacing, seed and soil treatment with bio-fungicide and application of Integrated Pest Management (IPM) module for the management of diseases and insects.

Result: The result of the CFLDs showed that on an average yield of chickpea seed under improved technology, ranged from $11.41 \mathrm{q} / \mathrm{ha}$ to $20 \mathrm{q} / \mathrm{ha}$ which was 25.06 per cent more as compared to farmer practices. The study depicted, the mean technology gap of $9.01 \mathrm{q} /$ ha, the mean extension gap of $3.70 \mathrm{q} / \mathrm{ha}$ and the mean technology index of 36.7 per cent. The study concluded that from one hectare a net income of Rs. 47565/- can be obtained, additional return of Rs. 10404/, effective gain of Rs. 8289 and B:C ratio obtained were 2.63 under incorporation of improved technology as compared to local check. By conducting CFLD of proven technologies, yield of crop could be enhanced to a great extent with ultimately increment in the income level of small and marginal farmers.
\end{abstract}

Key words: B:C ratio, CFLD, Chickpea, Extension, Technology gap.

\section{INTRODUCTION}

Chickpea or gram (Cicer arietinum L.) is a major Rabi pulse crop grown around the world. Being a leguminous crop, it can form nodules and fixes atmospheric nitrogen in symbiotic contact with the bacteria. Chickpea is a rich source of protein (24\%), carbohydrates (59.6) and minerals (3.2\%). It plays an important role in vegetarian human diet as well as for improving soil fertility for sustainable agriculture. India is the largest producer and consumer of chickpea in the world. Chickpea plant has a strong tap root system that penetrates deep into the soil that makes it suitable for growing in drought condition. The tap root system of chickpea with more number of lateral roots that occur in upper part of rhizosphere is beneficial for quick growth as well as more ground coverage prevents the soils from erosion and protects root from soil borne diseases (Mallikarjun et al., 2020). Chickpea is grown on an area of 10.17 million hectares with production of 11.35 million tones and the average productivity is $11.16 \mathrm{q} /$ ha (DES, 2021) in the country. The major chickpea cultivation states in India are Madhya Pradesh, Rajasthan, Maharashtra, Uttar Pradesh, Karnataka and Andhra Pradesh. In Haryana, chickpea occupies a larger position in terms of area, production and productivity among the pulse crops.

Chickpea productivity is affected by stressors (abiotic and biotic) due to partial adoption of new technologies at the farmer level. During the last few years, chickpea
Krishi Vigyan Kendra, ICAR-National Dairy Research Institute, Karnal-132 001, Haryana, India.

Corresponding Author: Rakesh Kumar, Agronomy Section, ICARNational Dairy Research Institute, Karnal-132 001, Haryana, India. Email: drdudi_rk@rediffmail.com

How to cite this article: Leharwan, M., Singh, M., Kumar, R., Saraswat, P.K., Kumar, Y. and Kumar, T.V.A. (2021). Assessment of Yield Gaps and Economics through Frontline Demonstration in Participatory Mode on Chickpea (Cicer arietinum L.) under Eastern Zone of Haryana. Legume Research. DOI: 10.18805/LR-4779.

Submitted: 31-08-2021 Accepted: 08-10-2021 Online: 18-11-2021

production and productivity has increased due to inclusion of high yielding varieties (Dhllion et al., 2021). The productivity can be further increased by adopting better crop management practices (Kumar, 2014). The low yield of chickpea in farmers' fields is due to large gaps in recommended technology and farmers' practices. Technology gaps varies with soil fertility status and weather condition. Singh and Singh, 2020 studied technology gap and technology index under CFLD of chickpea variety DCP 92-3. Prior to conducting the front-line demonstrations, group meeting and specific skill trainings were conducted. All other steps like selection of farmer, site selection, farmer's participation etc. were followed as suggested by Kirar et al. (2004). For minimizing these gaps, the Indian Council of 
Agricultural Research (ICAR), New Delhi introduced CFLD under National Food Security Mission (NFSM) during mid eighties. The objective of this programme is to demonstrate latest crop production, protection technologies under farmers' field condition by the close supervision of subject matter specialists of KVKs and to minimize the adoption gap. To convince the chickpea growers as well as nongrowers on effectiveness of technology and to motivate them for adoption, laying out of demonstration at farmers own field is one of the proven methodologies. This also benefits farmers and extension personnel by getting knowledge about latest and improved technologies. In view of this, to evaluate the effectiveness of frontline demonstration, KVK, ICARNDRI, Karnal conducted CFLD on chickpea crop in participatory mode in different selected villages of Karnal district.

\section{MATERIALS AND METHODS}

CFLD of chickpea were carried out by KVK, ICAR-NDRI, Karnal (Haryana) during Rabi season from 2017-18 to 202021 (4 consecutive years) in 6 blocks viz., Assandh, Gharaunda, Indri, Karnal, Nilokheri and Nissing of Karnal district that are categorized under Eastern zone (HR-1) as per the agro climatic Zones of Haryana. A total 220 demonstrations were conducted on chickpea in an area of 80 ha. The common soil of the region is loam and sandy loam and its major components reported were, organic matter $(0.36 \%$ to $0.69 \%)$, nitrogen (115 to $193 \mathrm{~kg} / \mathrm{ha})$, phosphorus (9 to $46 \mathrm{~kg} / \mathrm{ha}$ ) and potassium (126 to $456 \mathrm{~kg} / \mathrm{ha}$ ) (Gyawali, 2016). Under CFLD programme, 0.4 ha area is allotted for each farmer and adjoining 0.4 ha was considered local check (farmers' practice). Farmers were provided with critical inputs like improved variety seed (HC-1) in 2017-19 and (HC-5) in 2019-20. Seed and soil were treated with Trichoderma viride, weedicides, fungicides and insecticides were arranged from the scheme budget and remaining inputs by farmers themselves. Farmers were trained and advised to use a seed rate $50 \mathrm{~kg} / \mathrm{ha}$. The sowing method keeping $30 \times 10 \mathrm{~cm}$ spacing was demonstrated in their field. For fertilizer management, application of $15 \mathrm{~kg}$ nitrogen, 40 $\mathrm{kg}$ phosphorus and $25 \mathrm{~kg}$ zinc sulphate in the form of Urea, DAP and Zinc (21\%) were applied to the soil. The seed before sowing was treated with Trichoderma viride at the rate $5 \mathrm{gm} / \mathrm{kg}$ of seed, soil treatment were also carried out with Trichoderma viride at the rate of $2.5 \mathrm{~kg}$ with $100 \mathrm{~kg}$ of farm yard manure (FYM)/ha, weed management with Pendimethalin 2.5 litre/ha 1-2 days after sowing, cutworm and pod borer insect were managed by cypermethrin 25 $\mathrm{EC}$ at the rate $250 \mathrm{ml} / \mathrm{ha}$ and for disease management Mancozeb (Indofil M-45) at the rate 2-3 gm per litre of water. In farmer's practice (control), traditional cultivation methods were followed by using existing varieties. After sowing, KVK scientists regularly visited the demonstration to ensure proper guidance to the farmers. During the different stages of the crop, field visits, group meetings and field days were organized to aware the non - beneficiary farmers to witness the benefits of the demonstrated technology. Observations were collected from both recommended practices as well as farmers' practices and the collected data were analyzed. Different parameters such as yield, technology gap, extension yield and technology index were used for calculating gap analysis as suggested by (Kumar, 2014) as per formula given below:

Technology gap = potential yield $(\mathrm{Kg} / \mathrm{ha})$ - Yield of improved technology $(\mathrm{Kg} / \mathrm{ha})$

Extension Gap = Yield of improved technology $(\mathrm{Kg} / \mathrm{ha})$ - yield under farmers' practices $(\mathrm{Kg} / \mathrm{ha})$

Technology index=

$\frac{\text { Potential yield }- \text { yield of improved technology }}{\text { Potential yield }} \times 100$

Additional cost $(\mathrm{Rs} / \mathrm{ha})=$ Improved technology cost-farmer practice cost

Additional returns $(\mathrm{Rs} / \mathrm{ha})=$ Improved technology returns Farmers' Practice returns

Effective gains $=$ Additional returns - Additional cost

\section{RESULTS AND DISCUSSION}

Before conducting CFLDs, at farmers' fields, the KVK organized survey and based on the survey and farmers' feedback, major gaps were observed between improved technologies and farmers' practices of chickpea cultivation in Karnal district of Haryana (Table 1). The improved technologies included seed variety, seed rate, seed treatment, soil treatment, spacing, fertilizer management, weed management and plant protection. Under farmers' practices, generally seeds of local variety were sown instead of latest variety with high potential yield and resistance to diseases. These gaps observed at the farmer's field are due to the unavailability or lack of accessibility to new improved technological practices (Shivran et al., 2020). Based on these observed gaps under CFLD, improved variety seed of HC-1 and HC-5, bio-control Trichoderma viride for seed and soil treatment, herbicides for weed management, fungicide and insecticide for plant protection measure were provided to the farmers by KVK, ICAR-NDRI, Karnal and other components were taken care in participatory mode under the supervision of KVK experts. These findings were similar to the observations reported by Kumar (2014) and Meena et al. (2021).

\section{Yield}

Result of 220 demonstration conducted during 2017 to 2021 on 80 ha area on farmer's field of Karnal district presented in Table 2 concluded that the average yield of chickpea through improved technology surged from 11.41 to $20 \mathrm{q} / \mathrm{ha}$ as compared to 9.40 to $14.82 \mathrm{q} / \mathrm{ha}$ in farmers' practices (local check). Average yield of total 220 demonstrations was 15.98 $\mathrm{q} /$ ha from improved technology whereas; the average yield from farmers' practices was $12.28 \mathrm{q} / \mathrm{ha}$. It was observed that improved technology yield increased 21.38 to $37.50 \%$ over farmers' practice. The result clearly revealed that the 
increase in yield in demonstration over farmers' practice was the impact of improved production technology of chickpea demonstrated by KVK in the different regions of Karnal district. Similar results were recorded by Dhillon et al (2021) and Wadkar et al (2018).

\section{Technology gap}

The data from Table 3 showed that the technology gap in demonstration yield against potential yield ranged from 5 to $10.70 \mathrm{q} /$ ha during four years of demonstration. Technology gap was maximum (13.59 q/ha) with demonstration variety HC-5 during 2019-20 and minimum with HC-1 (5.0 q/ha) during 2017-18. On an average, technology gap during four years of demonstration were $9.01 \mathrm{q} / \mathrm{ha}$ for chickpea cultivation in Karnal district. The increase in technology gap during the year 2019-20 and 2020-21 was due to harsh weather condition at crop maturity. Similar findings were recorded by Kumari et al., 2020 where the technology gap ranged from 2.46 to $4.95 \mathrm{q} / \mathrm{ha}$ which was close to the gap discussed in present study for the year 2017-18 and 2018-19.

\section{Extension gap}

Data (Table 3) showed that the extension gap ranging 2.01$5.18 \mathrm{q} / \mathrm{ha}$ was observed between improved technology and farmers' practices during the period of demonstration. The extension gap was more in $\mathrm{HC}-1$, that is $5.18 \mathrm{q} / \mathrm{ha}$ in the year 2017-18 and less in $\mathrm{HC}-5$, that is $2.01 \mathrm{q} / \mathrm{ha}$ in the year 2019-20 respectively. It was observed that during the period of evaluation, average extension gap was $3.70 \mathrm{q} / \mathrm{ha}$ for the chickpea varieties HC-1 and HC-5 in Karnal district. These

Table 1: Details of technology intervention and farmers' practices under FLDs on chickpea in Karnal district of Haryana.

\begin{tabular}{|c|c|c|c|}
\hline Technology component & Improved technology & Farmers' practices & Gap \\
\hline Farming situation & Irrigated & Irrigated & $\mathrm{Nil}$ \\
\hline Variety & $\mathrm{HC}-5$ & Local seed (Old variety) & Partial \\
\hline Seed rate $(\mathrm{kg} / \mathrm{ha})$ & 50 & 40 & Partial \\
\hline spacing & $\begin{array}{l}\text { Row to row } 30 \mathrm{~cm} \text {, plant to plant } \\
10 \mathrm{~cm} \text { and depth } 5-7 \mathrm{~cm}\end{array}$ & $\begin{array}{l}\text { No proper spacing and seed } \\
\text { is placed deep in soil }\end{array}$ & Partial \\
\hline Seed treatment & $\begin{array}{l}\text { Seed treatment with Carbendazim @ } 1.5 \mathrm{~g} / \mathrm{kg} \\
\text { seed, Trichoderma viride @ } 5 \mathrm{~g} / \mathrm{kg} \text { seed }\end{array}$ & No seed treatment & Partial \\
\hline Bio-fertilizer & $\begin{array}{l}\text { Rhizobium and PSB culture } \\
@ 600 \mathrm{gm} \text { each/ha seed }\end{array}$ & Rarely bio-fertilizer inoculation & Partial \\
\hline Soil treatment & $\begin{array}{l}\text { Trichoderma viride @ } 2.5 \mathrm{~kg} \text { with } \\
100 \mathrm{~kg} \text { F.Y.M/ha or } 50 \mathrm{~kg} \text { vermicompost. }\end{array}$ & No soil treatment & Partial \\
\hline Fertilizers & $\begin{array}{l}\text { Nitrogen-15 kg/ha., Phosphorus } 40 \mathrm{~kg} / \mathrm{ha} \\
\text { and Zinc sulphate } 25 \mathrm{~kg}(21 \%) \text { per ha }\end{array}$ & $\begin{array}{l}\text { Nitrogen-48kg/ha, no phosphorus and zinc } \\
\text { fertilizer application, (Non judicious use) }\end{array}$ & Partial \\
\hline Weed management & $\begin{array}{l}\text { Pendimethalin ( } 30 \% \text { EC) @ } 2.5 \mathrm{l} / \text { hectare } \\
\text { in } 600 \text { litre of water as pre-emergence and } \\
\text { followed by one hand weeding and topping. }\end{array}$ & One-time hand weeding & Partial \\
\hline Insect management & $\begin{array}{l}\text { Cypermethrin } 25 \text { E.C @ } 250 \mathrm{ml} / \mathrm{ha} \\
(0.5 \mathrm{ml} / \text { lit. water })\end{array}$ & Non judicious use of insecticides & Partial \\
\hline Diseases management & Mancozeb (Indofil M-45) @ $3 \mathrm{~g} / \mathrm{l}$ of water & Non judicious use of fungicides & Partial \\
\hline
\end{tabular}

Table 2: Yield performance and yield analysis of demonstrated chickpea variety in Karnal district of Haryana.

\begin{tabular}{lcccccc}
\hline Year & $\begin{array}{c}\text { No. of } \\
\text { Demo. }\end{array}$ & $\begin{array}{c}\text { Area } \\
\text { (ha.) }\end{array}$ & $\begin{array}{c}\text { IT average yield } \\
(\mathrm{q} / \mathrm{ha})\end{array}$ & $\begin{array}{c}\text { FP average yield } \\
(\mathrm{q} / \mathrm{ha})\end{array}$ & $\begin{array}{c}\text { \% increase in } \\
\text { yield over FP }\end{array}$ & $\begin{array}{c}\text { IT Yield over FP } \\
(\mathrm{q} / \mathrm{ha})\end{array}$ \\
\hline $2017-18$ & 20 & 57 & 20 & 14.82 & 34.95 & 5.18 \\
$2018-19$ & 20 & 59 & 18.22 & 14.50 & 25.65 & 3.72 \\
$2019-20$ & 20 & 50 & 11.41 & 9.40 & 21.38 & 2.01 \\
$2020-21$ & 20 & 54 & 14.30 & 10.40 & 37.5 & 3.90 \\
Total/Mean & 80 & 220 & 15.98 & 12.28 & 29.87 & 3.70 \\
\hline
\end{tabular}

Table 3: Gap analysis in chickpea under front line demonstration and farmers' practice.

\begin{tabular}{lcccc}
\hline Season and year & Variety & Technology yield gap $(\mathrm{q} / \mathrm{ha})$ & Extension yield gap (q/ha) & Technology index $(\%)$ \\
\hline Rabi 2017-18 & HC-1 & 5.00 & 5.18 & 20.00 \\
Rabi 2018-19 & HC-1 & 6.78 & 3.72 & 27.12 \\
Rabi 2019-20 & HC-5 & 13.59 & 2.01 & 54.36 \\
Rabi 2020-21 & HC-5 & 10.70 & 3.90 & 42.8 \\
Mean & & 9.01 & 3.70 & 36.07 \\
\hline
\end{tabular}




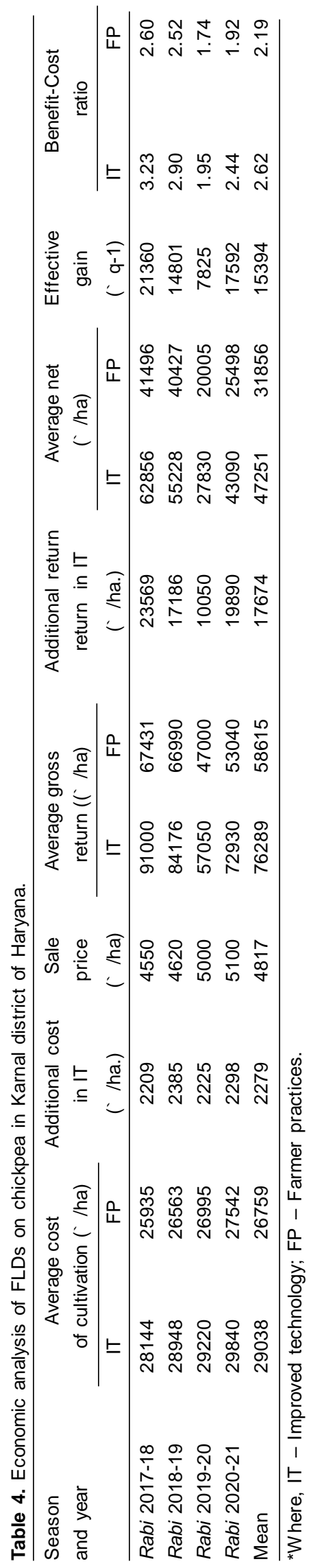

findings are in corroboration with the findings of Patel and Patel, 2020. The higher value of technology gap and extension gap during 2017-18 to 2020-21 emphasized the need to educate the farmers through various methodologies for increasing the adoption of improved or recommended technology which eventually lead to decrease the gap.

\section{Technology Index}

The technology index (Table 3) shows the feasibility of the evolved technology at farmers' field. Lower the value of index more is the feasibility of technology. Result on technology index shows that it varies from $20-54.36 \%$. During the four years of study the highest technology Index 54.36 per cent and lowest 20 per cent was recorded during year of 201920 and 2017-18 respectively.

\section{Economics}

Economics of recommended technology under FLD were calculated (Table 4) based on prevailing market rates and recorded higher gross return (Rs. 91,000/ha), net return (Rs. $62,856 / \mathrm{ha}$ ) and effective gain (Rs. 21,360/ha) with improved technology demonstration compared to farmer's practice in the year 2017-18 in $\mathrm{HC}-1$ variety. Under the present study, higher net return ranged from Rs 27,830 to 62,856 /ha over four years and its mean value was Rs 47,565/ha. However, in farmer's practices the net return ranged from Rs. 20,005 to Rs. $41,496 /$ ha over four years and its mean value was Rs. 31,856/ha. The demonstration of chickpea organized during four consecutive year in Karnal district gave an average additional return of Rs. 17,673.75/ha. Similar result was documented by Jha et al., 2020 where the additional return ranged from Rs. 22000 to Rs. 25,838. The benefit cost ratio was maximum (3.23) in improved technology in year 2017-18 in HC-1 variety and was minimum (1.95) in the year 2019-20 in HC-5 variety. However, under farmers' practices' maximum benefit cost ratio recorded was 2.62 in 2017-18 and minimum (1.74) in 2019-20.

\section{CONCLUSION}

Results of present investigation concluded that cultivation of chickpea by improved technologies through frontline demonstration created more awareness and motivated the other farmers to adopt suitable production technology. However, various components like adjustment in sowing time, balanced fertilizers, high-yielding varieties, weed, insect-pests and disease management were important in achieving more productivity and maximum benefit. Both extension and technology gap reduction is essential to further increase the production. It can be achieved by demonstrating/educating recent technologies and methodologies in agriculture to the farming community. Demonstration of improved chickpea production technology satisfied partner farmer to adopt the technology for better income in Karnal district of Haryana. It also will leave a longterm impact on production and productivity of crops and that in turn changes or uplifts the livelihood of farmers. 


\section{REFERENCES}

Agricultural Statistic at a Glance. (2021). Department of Agriculture and Cooperation, Directorate of Economics and Statistics, Ministry of Agriculture and Farmer welfare, Government of India. Fourth Advance Estimate 2020.

Dhillon, A., Kumar, N., Kumar, R., Shivran, A., Kumar, S. and Singh, N. (2021). The impact of front-line demonstrations on yield and profitability of chickpea (Cicer arietinum) in the Mahendergarh district of Haryana, India. International. 32-35.

Gyawali, C., Dahiya, D.S., Devraj, Bhat, M.A. and Bhandari, R.R. (2016). Spatial distribution of physic-chemical properties and macronutrients in rice growing soil of Haryana. The Eco-scan. 10(3 and 4): 365-370.

Jha, A.K., Chatterjee, K., Mehta, B.K. and Kumari, M. (2020). Assessment of technological interventions on productivity and profitability of Chickpea (Cicer arietinum I.) Through cluster frontline demonstrations (CFLDs) in Sahibganj district of Jharkhand. International Journal of Advanced Biological Research. 10(4): 213-217.

Kirar, B.S., Mahajan, S.K. and Nashine, R. (2004). Impact of technology practices on the productivity of soybean in FLD. Indian Research Journal of Extension Education. 5(1): 15-17.

Kumar, R. (2014). Assessment of technology gap and productivity gain through Crop technology demonstration in chickpea. Indian Journal of Agricultural Research. 48(2): 162-164.

Kumar, R. (2014). Crop technology demonstration: an effective communication Approach for dissemination of wheat production technology. Agricultural Science Digest. 34 (2): 131-133.
Kumari, N., Thakur, A.K. and Kaith, N.S. (2020). Assessment of Yield Gaps in Chickpea Production in Shimla District of Himachal Pradesh. International Journal of Economic Plants. 6(3):143-146.

Mallikarjun, Ram, H., Kumar, R., Singh, M., Meena, R.K. and Kumar, R. (2020). Effect of Rhizobium Inoculation and Tillage Practices on Fodder Cowpea (Vigna unguiculata). Legume Research. 10.18805/LR-4373.

Meena, R.K., Singh, B., Chawla, S., Meena, R.K. and Shinde, K.P. (2021). Evaluation of frontline demonstrations of chickpea under irrigated North Western Plain Zone-1b of Rajasthan. Journal of Pharmacognosy and Phytochemistry. 10(1): 1240-1244.

Patel, B.K. and Patel, R.A. (2020). Impact of cluster frontline demonstration programme on the yield of Chickpea (Cicer arietinum I.) In Mehsana district of Gujarat, India. International Journal of Environment, Agriculture and Biotechnology. 5(4): 901-906.

Shivran, R.K., Singh, Ummed, Naval, K., Singh, K.B. and Keshav, P.R.M. (2020). Gap analysis and economic viability of front-line demonstration in Indian Mustard (Brassica juncea L.) under hyper arid partial irrigated zone of Rajasthan. International Journal of Bio-resource and Stress Management. 11(4): 353-360.

Singh, N. and Singh, A.K. (2020). Yield gap and economics of Cluster Frontline Demonstrations (CFLDs) on pulses under rain-fed condition of Bundelkhand in Uttar Pradesh. International Journal of Advanced Research in Biological Sciences. 7(8): 1-7.

Wadkar, J.R., Tijare, B.R., Giri, M.D., Jaybhaye, C.P., Chavhan, R.T., Bawkar, Sarap K.W. (2018). Impact of frontline demonstration on the yield and economics of chickpeain Buldhana district of Maharashtra, India. International Journal of Current Microbiology and Applied Science. 6: 311-314. 